\title{
Applying a Counterfactual: Would 1966 Ugandan University Students Be Surprised by Ugandan Governance Today?
}

\author{
Nelson Kasfir
}

\begin{abstract}
Joel Barkan surveyed Ugandan university students' attitudes in 1966 and worked on Ugandan national governance three decades later. These two inquiries facilitate an unusual counterfactual analysis. Counterfactuals typically test historical explanation by manipulating an antecedent to estimate change to a known outcome. But a counterfactual can be constructed to examine how an antecedent would react to a later activity. By extrapolating from 1966 students' responses to Barkan's survey and their expected knowledge of political events, we can estimate their likely attitudes to later governance. Applying this unconventional counterfactual helps establish how far prior perception of politics illuminates later governmental practice.
\end{abstract}

Résumé: Joel Barkan a examiné les attitudes des étudiants de l’Université ougandaise en 1966 et a travaillé sur la gouvernance nationale ougandaise, trois décennies plus tard. Ces deux enquêtes facilitent une analyse contrefactuelle inhabituelle. Généralement, l'analyse contrefactuelle teste une explication historique en manipulant un antécédent pour estimer le changement vers un résultat connu. Mais une analyse contrefactuelle peut être aussi construite afin d'examiner comment un antécédent réagirait à une activité ultérieure. En extrapolant à partir des réponses

African Studies Review, Volume 59, Number 3 (December 2016), pp. 139-153

Nelson Kasfir is a professor of government emeritus at Dartmouth College. He writes frequently on Ugandan and African politics and currently is writing a book on governance of civilians by rebels in Uganda. He is the co-author of a chapter on the Ugandan Parliament in Joel Barkan's Legislative Power in Emerging African Democracies (Lynne Rienner, 2009) and co-editor of Rebel Governance in Civil War (Cambridge, 2015). E-mail: Nelson.M.Kasfir@Dartmouth.edu 
des étudiants en 1966 à l'enquête de Barkan et leurs connaissances escomptées des événements politiques, nous pouvons estimer leurs attitudes susceptibles de gouvernance plus tard. L'application de cette analyse contrefactuelle non conventionnelle permet d'établir dans quelle mesure une perception préalable de la politique informe plus tard les pratiques gouvernementales.

Keywords: Counterfactuals; university students; political attitudes; Ugandan governance; patronage; corruption; competitive politics; one-person rule

After beginning his research in Uganda by surveying university students in 1966, Joel Barkan returned there three decades later, during the last period of his scholarship, to investigate basic factors shaping Uganda's national governance. While the issues he analyzed in each era were completely different, they raise a fascinating question when considered together. Would those early Ugandan university students have been surprised by later Ugandan government practices, or would they say these were just what they had expected ${ }^{1}$ Can we predict their opinions about current government practices, particularly the persistence of and corruption in Yoweri Museveni's long-running presidency by extrapolating from their perspectives on their political rulers during the country's first decade after independence? What would they have thought in 1966 if they had the ability then to gaze into the future? To ask this question is to pose a counterfactual, although an unusual version of the form this new field of social science inquiry typically takes.

\section{Counterfactuals}

What knowledge can be generated by applying the results of a survey to events occurring years in the future that could not have been known by the respondents at the time? If social science must be based solely on facts (presuming we know what "facts" are), the answer must be "nothing." We would waste our time speculating how changing contexts would alter the judgments of respondents-whose potentially differing responses to later events could never be individually identified from their anonymous survey submissions. There would seem to be no check on the imagination of a later researcher reinterpreting the work of the original investigator.

But over the last two decades the development of counterfactuals as a technique for evaluation of conclusions in social science suggests otherwise (Lebow 2000, 2009; Tetlock \& Belkin 1996). A counterfactual is a "what if" assertion in which an outcome is postulated that is contrary to what actually occurred. Counterfactuals test explanations. They provide alternative arguments based on completeness, evidence, and internal consistency rather than on external validity. Not every choice of a counterfactual facilitates evaluation. However, criteria exist for selecting useful counterfactuals. Perhaps the most important are that a counterfactual assertion be plausible, clear, 
and logically consistent, and that it rewrite history only minimally (Lebow 2000; Tetlock \& Belkin 1996).

Inquiry into counterfactuals has focused entirely on manipulating an antecedent, that is, an event (or events) thought important to an outcome, in order to ask what plausible change, if any, would then likely occur as the consequent. One famous example asks how European history would have changed if Archduke Franz Ferdinand's driver had neither lost his way nor accidentally stopped his car in front of Gavrilo Princip, thus avoiding the Archduke's assassination and perhaps the First World War. Another much discussed counterfactual inquires whether the United States would have invaded Iraq had Ralph Nader not run in the 2000 presidential election, plausibly allowing $\mathrm{Al}$ Gore to win.

Consider an alternative form of counterfactual. Suppose we pose a known future to past actors whose attitudes or behaviors during earlier events are also known. By examining these past responses, we may be able to construct a persuasive account of their reactions to future events they had not experienced. The consequent becomes "known" to the antecedent actor through our inspection of their earlier responses. As in conventional counterfactuals, we manipulate the antecedent, but we do so by "exposing" it to a future state of affairs rather than changing it. We create a different sort of counterfactual.

The question becomes one of imagining how a group or individual from an earlier period would react to some event occurring at a later time. An easy case to imagine is the profit-seeking response of a rational investor from an earlier era to changes in investment opportunities after the abandonment of the gold standard. A harder one is to estimate whether President Dwight Eisenhower's 1961 fear of unwarranted influence exercised by the military-industrial complex would cause him to express strong opposition to contemporary deregulation of corporate contributions to American political campaigns. One benefit in posing the question would be to gain a wider perspective on a more recent event or pattern of behavior. Another would be to assess how much later events resemble earlier ones as a test of how much they owe to their past. Can we imagine actors who lived in years past reacting to a future by saying "we've seen this before!"?

One methodological question for creating this sort of counterfactual is determining what counts as data. How should we limit the range of potential data that might have formed the attitudes of university students in 1966 and what factual information they would have known in order to predict how they would react to current Ugandan government practice? These are daunting conceptual issues. For purposes of this forum, I restrict the relevant knowledge of 1966 university students to the data Barkan gained from his questionnaire and to Ugandan political events they would probably have known about by the time he administered the questionnaire. I also presume that what those students would have learned about Ugandan government practice between 1996 and 2010 consists only of what Barkan (and his later co-authors) wrote about. ${ }^{2}$ 
However, we need to ask whether the fact that most of these students joined the government contaminates this counterfactual. How much did their own bureaucratic actions actually shape the Museveni government that I am "asking" them to evaluate? ${ }^{3}$ The more these students could be shown to influence the implementation of the government's policies, the more trivial any finding that they considered the later regime "familiar." Current Ugandan officials, particularly those in top executive positions that regulate most policies, generally graduated from Makerere University, where the survey was administered, although in recent years also from other Ugandan universities. Can we regard the attitudes of the $1966 \mathrm{stu}-$ dents Barkan surveyed as characterizing the views of Ugandan civil servants today? Accepting this argument would essentially nullify the counterfactual asserted here.

Granted that the activities of officials would always be essential information for evaluating any government's policies and their outcomes, gathering sufficient data even to make an informed conjecture seems impossible in this case. By themselves, even the three years of university students that Barkan surveyed could have made only a small contribution to the attitudes or behavior of contemporary officials as a whole. Since the largest group among those sampled intended to become teachers, we might hazard a guess that these students made even less of an impact on government policies than their numbers might suggest. We might imagine that running Barkan's survey on the following batch of students to enter Makerere University would produce similar responses. But Barkan, a good methodologist, would be the first to warn us against inferring similarity from different populations, even when most conditions remain the same.

In Uganda, even a plausible degree of similarity among the attitudes of succeeding generations of students could not be defended for long. The advent of Idi Amin's rule five years after Barkan surveyed university students changed so many basic conditions that it would be a heroic assumption to expect the attitudes of 1966 university students to describe those of their counterparts a decade later. The rapid expansion of corruption and insecurity undoubtedly changed the expectations and attitudes of most later Makerere students. The overthrow of Amin in 1979 led to new regimes that changed additional conditions while continuing to perpetuate corruption and insecurity. To a large extent, the Museveni regime managed to restore security, although without achieving much, if any, reduction in bureaucratic corruption. Using Barkan's 1966 survey data hardly confounds the counterfactual I develop here.

\section{University Student Attitudes in 1966}

Barkan began the research for his doctoral dissertation by distributing two self-administered attitude surveys, each to half of all the thirteen hundred students enrolled in Makerere University College (now Makerere University) in November 1966. One survey asked for student perceptions 
of incumbent elites, the issue of interest here. ${ }^{4}$ Over the next year he distributed the questionnaire to Tanzanian and Ghanaian university students as well. His analysis of the responses of students on the three campuses was published in his first book, An African Dilemma (1975a). Barkan summarized the results for all three universities, and broke down the responses by campus. He discussed political events in each country that likely accounted for the differences in student answers. Here I limit my discussion to the Ugandan survey, recognizing, however, as Barkan did, that perhaps onethird of Makerere responders were not Ugandans. ${ }^{5}$

The answers of Ugandan students might have been influenced by their political context. By 1966 Uganda's political troubles had already begun to spiral out of control, as Barkan reminded us. By November 1966 the national leader, Milton Obote, had made himself president, arrested five ministers from his own party who had led an effort to remove him through a parliamentary motion to investigate him, introduced a new constitution, and subdued Buganda, the country's largest kingdom, through military action. Obote's party "had withered into a 'no-party' state" (Barkan 1975a:49). Yet the campus remained calm and seemed isolated from these dramatic changes, as Barkan noticed. ${ }^{6}$ In addition, as he also pointed out, over 90 percent of students in all three countries held government scholarships and over 80 percent of them intended to work for the government after graduation.

Barkan insisted throughout the study that these students' educational socialization, rather than their social backgrounds, produced the cognitive framework that dominated their attitudes and value judgments. In his view, their education led them to regard themselves as "future members of a technocratic upper-middle class or organization men [and women] rather than members of a presumptive ruling elite" (1975a:187). ${ }^{7}$ Unlike the generation graduating slightly before or at independence, which regarded itself as "a presumptive ruling elite . . . interested in political affairs," these students tended to be uninterested in taking active political roles (1975:189). They considered themselves as likely bureaucrats, yet equally indispensablewilling to accept political authority, so long as leaders did not deprive them of security and well-paying positions. ${ }^{8}$ Thus, they did not see themselves as risk-takers. They did see themselves as holding different values and occupying a different class status from their uneducated compatriots, the overwhelming majority of the population. The reason may have been that throughout the '60s university students increasingly were themselves the children of educated parents. And one of their values was a strong desire to escape from rural life in their future occupations.

The central argument of the Barkan's 1975 book was taken from the "African dilemma" in its title. What Barkan meant was that African university students who had been socialized into these values were not well prepared for the tasks of economic and political development that their countries confronted, despite the large investment that had been made in their education. If, Barkan asserted, economic development requires selfsustaining growth, the educated must engage in entrepreneurial activities, 
tasks to which these students were not attracted. Rather than being ambitious, they were content to rise through a system of seniority. They were more interested in spending their salaries on consumer goods that served as status symbols than in investing in productive enterprises. In regard to political development, Barkan concluded that these students showed themselves to be careerists who would serve whatever government was in power and overlook its violations of law. They would not resist military coups or unconstitutional extensions in office by elected civilian leaders as long as the regime maintained the "privileges and authority of the educated class" (1975a:157). The "dilemma," then, was the problem of how postindependence African polities could "become qualitatively different" if "the educational system remain [ed] essentially a colonial institution” (1975a:158).

In order to apply these 1966 university students' notions of authority and legitimacy and their perceptions of their contemporary incumbent elites to determine how they would evaluate Museveni and the National Resistance Movement (NRM) government in its later years, we need to identify the categories through which they judged authority figures. In choosing whether political policies ought to be made by the most educated or by elected officials, Ugandan students, according to Barkan, on average leaned somewhat toward technocratic decision-making. In deciding whether a political system should be based on democratic or authoritarian procedures, their choices averaged at the mid-point. ${ }^{9}$

Putting these two dimensions into a fourfold typology of polities, Barkan characterized Ugandan students overall as preferring a somewhat technocratic political system, while expressing ambiguity about its democratic character. He suggested that these "students opted for a type of political system that is probably most similar to that which existed in the [late] colonial period" (1975a:147). However, their mean scores masked relatively large subsets of students who preferred an extreme type of polity, either an authoritarian technocracy or a participatory democracy. Inspecting the proportion of all Ugandan students who fit more distinctively in one or the other subset, Barkan discovered 3.5 times as many authoritarian technocrats as participatory democrats-a greater proportion than among their counterparts in Tanzania and Ghana. ${ }^{10}$

To examine Ugandan students' perceptions of incumbent elites, Barkan asked them about different types of officials. ${ }^{11}$ A majority of these students regarded MPs and army officers as "not very qualified" for the positions they held and ministers as "somewhat qualified" (1975a:167). By similar percentages, they also felt their own qualifications were superior to those of MPs and army officers. Almost half (44\%) regarded ministers as having the same qualifications as they did. On the other hand, almost a majority $(47 \%)$ considered Permanent Secretaries, the top civil servants, as "highly qualified," and half thought they possessed superior qualifications to their own. ${ }^{12}$

Barkan also examined whether students' positive or negative perceptions of the polity at the time of the survey influenced their sense of their political efficacy. ${ }^{13}$ Four-sevenths of the Ugandan students who had positive 
perceptions felt they could exert "some" or "a great amount of influence" over government decisions, while three-quarters of those who perceived the polity negatively felt they would have "very little influence" (1975a:179). Over half of those with positive perceptions thought they would receive serious consideration if they brought a problem of their own to an official, while seven-eighths of those with negative perceptions believed they would not. In a telling insight into the state of political communication in Uganda, three-fifths of those with a positive view and nine-tenths with negative opinions believed that average citizens don't understand public issues because officials "do not help the people to understand," not because people don't care or find issues too complicated (1975a:180).

\section{Ugandan Governance Practices from 1996 to 2010}

In the 1990s Barkan undertook fieldwork on Ugandan national governance, a project he pursued intermittently through 2012. Often working with other researchers during this period, he developed an account of how the government functioned during the second phase of the Museveni and NRM regime. ${ }^{14}$ This account centered on the nature of political control by the "Movement" and the political party that emerged from it. ${ }^{15}$ It articulated the centrality of corruption and the transition from no-party to party to one-person rule. ${ }^{16}$ Later, he and his associates extended their examination to the government's conduct of the long-running war in the north, and in 2011, to other issues involving Uganda's neighbors.

In a 2004 report to the World Bank (Barkan et al. 2004), Barkan and his colleagues divided the Museveni period into early and late phases; "looking back," they stated, "the elections of 1996 were the 'high watermark' of President Museveni's tenure in office" (2004:13). From that point forward, approval of the president declined, his personal dominance of politics grew, government corruption rose, and elections became less free and fair. In 1998 these traits had not been as apparent: still, in that year Barkan and his colleague, M. A. Thomas, had seen that "Uganda's advances are slowing, and are in danger of reversing, as political power becomes more personalized in President Museveni, and as the Movement's monopoly on power is institutionalized and extended" (Thomas \& Barkan 1998b:26). By 2004, however, the perception was that "the President [has begun] to look increasingly like . . . a neopatrimonial ruler (i.e., 'big man') at the helm of a clientelist state" (Barkan et al. 2004:14).

Building on the work of other analysts, Barkan and Thomas viewed Uganda as an example of reliance on patronage politics found generally among African states in the 1990s. They suggested (Thomas \& Barkan 1998a) that governance based on patronage in Africa typically results from a few interrelated traits. African governments supply most of the available jobs. These jobs are distributed through informal connections among small elites. Governments have limited capacity to oversee job performance. Consequently, officials are able systematically to structure rewards 
to establish political loyalty. In this context, they insisted that "“corruption' . . is not incidental to politics, but the very reason for engaging in politics" (1998a:3). The 2004 report elaborated this analysis by noting "the ever increasing reliance on patronage and prebends" (Barkan et al. 2004:14), a notion Barkan later called "inflationary patronage" (2011:11).

The 1998 inquiry focused on whether the turn toward political liberalization and democratization in Africa during the 1990s had increased corruption. Constituent demands for material rewards created temptations for candidates to divert official funds during campaigns and for parties that controlled the state to divert them continuously. In particular, ruling parties used state regulations to coordinate both party and private businesses "to produce rents for the party and party members" (Thomas \& Barkan 1998a:15). While the public benefits of liberalization needed to be taken into account, "where a party is sufficiently dominant, it may engage in the self-dealing practices associated with one-party states notwithstanding political liberalization" (Thomas \& Barkan 1998a:21).

Applying this framework to Uganda, Thomas and Barkan (1998b) focused on the financing of the 1996 election campaigns and of constituency service, and especially the underwriting of the National Resistance Movement. Financial demands made by constituents, they argued, drove candidates to spend enormous sums-comparable, in fact, to the expenditures in U.S. elections despite the extreme divergence in income between the two countries. ${ }^{17}$ Constituency service, especially for ministers, created further burdens. Although the Movement legally received some government funds, it earned more through Danze Enterprises, an export-import company that was the NRM's most important business enterprise until it became hopelessly corrupt. Officials manipulated their political connections to make Danze profitable and diverted salaries intended for civil servants and soldiers, inflated costs of procurement, stole government property, and arranged privatization of public enterprises through sales to cronies at prices below fair market value. Thomas and Barkan accurately predicted in 1998 that despite parliamentary, media, civil society, and donor initiatives opposing corruption and aggrandizement of power, "the Movement is moving inexorably towards a one-party state" (1998b:24).

The 2004 report focused on three prominent issues: the impending transition from no-party to multiparty elections, the ongoing war against the Lord's Resistance Army (LRA), and corruption. ${ }^{18}$ These issues are interrelated, they asserted, because the transition, if it occurred, along with the war in the north, would exacerbate corruption. They also argued that corruption caused a growing drag on the economy that had been largely hidden by donor budget support and the government's adherence to prudent macroeconomic policies.

They interpreted the transition as a bid by Museveni to continue in office despite the constitutional limit of two terms. Barkan and his associates correctly anticipated that Museveni would achieve this objective by orchestrating the shift to multiparty competition with a constitutional 
amendment removing term limits, and they identified two reasons for expecting his success: "First, the apparent determination by the President and his colleagues to hold onto power at any cost. Second, the apparent growing role of the military and paramilitary organizations in Uganda's politics" (2004:27-28). 19

Like most observers, Barkan and his associates attributed the failure to negotiate an end to the long-running war in the north, which had devastated the Acholi subregion, as much to Museveni as to the LRA. In southern Uganda the war was popular. It also opened opportunities for military corruption, as senior commanders enriched themselves and the regime by manipulating soldiers' salaries and procurement as well as running businesses that supplied their troops (2004:39). The 2004 report also examined corruption in government offices and business activities involving allies of the regime. Members of Museveni's family had acquired lucrative contracts to run arms supply, aviation, banking, and airport handling firms, many of them acquired through the privatization process. Other illegal activities included smuggling (particularly gold from the Congo), banking, and opportunities to divert funds through public procurement, tax collection, and local government. The increase in local government positions through decentralization also became a fertile source of patronage and corruption. "Put simply," the report concluded, "endemic corruption is here to stay" (2004:57).

In 2011 Barkan reported growth in the same trends of patronage and militarization of politics; an increase in patronage and therefore corruption, particularly involving the first family, had become even more evident in Ugandan governance and private business. This was true because the regime was finding it increasingly difficult to meet rising demands for patronage, partly because donors had withdrawn budget support, funds that were easier to divert than those from donor project assistance. Payments from oil companies for capital gains taxes and signing bonuses provided new but limited discretionary funds, as oil would not be produced for several years. Barkan observed that the war in the north no longer posed an issue, although the independence of South Sudan offered a new potential battlefield for the Ugandan army, presenting further opportunities for corruption. ${ }^{20}$

Barkan, together with his associates, made three significant contributions to understanding the second phase of the Museveni regime. First, he identified specific networks of corruption and how they were related to political control. Second, he correctly predicted Uganda's continued consolidation of a clientelist system of governance under personal rule. Third, he identified the role of donors in supporting the corruption necessary to make this system work. Thus, he provided an explanation for why democratization in Uganda has continually stalled.

\section{Ugandan Student Reactions to 1996-2010 Ugandan Governance}

Suppose the students Barkan surveyed were teleported to the second phase of the Museveni and NRM period without passing through the successive 
periods of mass killings, the virtual disappearance of the rule of law, and two wars-or through the resurrection of hope that accompanied the NRM's first phase. It is safe to say that despite being unaware of the later postindependence history that intimately influences most Ugandans today, much post-1996 politics and governance would probably remind them of what they had already experienced in 1966 . The relative intensities of certain features of government would be surprising, but the contours of what they would "see" would likely seem familiar.

As budding technocrats not strongly wedded to electoral democracy, they would not be surprised by the overriding role of the NRM in political life today. They had seen the growth of a dominant party eclipse the opposition through Obote's political maneuvers during the first four years of independence. Knowing that Obote had introduced a new constitution that greatly increased his personal authority, they would recognize Museveni's manipulation of the 1995 constitution to ensure his persistence in office. Obote's willingness to act on his own to ensure his grasp on power would have prepared them for Museveni's insistence on personal control at the expense of institutional development. Museveni's move to one-person rule would not surprise them. Indeed, having observed Obote's shift to a more personal, patronage-based, and coercive rule, the shift from the first to the second phase of Museveni's regime would have struck a familiar chord with these students.

How would they feel about the post-1996 developments? As careerists fearful of taking risks, they would likely sympathize with bureaucrats who acquiesced in the second phase of Museveni's and the NRM's rule rather than opposing it. Unlike the NRM's first phase, when it seemed to embrace a mildly radical philosophy that these students might have feared would jeopardize their path to well-paying jobs and upper middle-class status, in its second phase this government would appear to support their aspirations for a quiet and relatively secure life. Their preference for a technocratic government maintaining a façade of free and fair elections would also, in their eyes, legitimate the NRM in its second phase. Most of them would likely be reluctant to support the new opposition parties that emerged after 1996. ${ }^{21}$ They would recognize them as just as weak as the opposition with which they were familiar, and it is not difficult to imagine that they would find similar reasons for this weakness.

The students were familiar with Obote's practice of patronage through awards of office and access to businesses and land to supporters during his first four years in office. Obote also offered ministerial positions to entice leading opposition MPs to cross the aisle. But his use of patronage seems quaint by comparison to Museveni's extraordinary reliance on it. The extent of the NRM government's dependence on patronage and corruption would probably astonish the students. Nevertheless, the 1966 "Gold Crisis" that had become public several months before they filled out their surveys for Barkan would lead them to expect political figures to embrace corruption. $^{22}$ They would have no trouble believing the accusations 
reported by Barkan in 2004 that Salim Saleh, Museveni's brother and close military and political confidante, had bought gold and avoided paying custom duties. However, they probably would not have anticipated the extensive demands for rewards and illegal use of official resources to finance political campaigning that Thomas and Barkan documented (1998b). Their knowledge of political campaigns was mostly limited to the preindependence elections of 1961 and 1962 administered by the Protectorate administration. While there is little data available, there are good reasons to assume those candidates generally avoided illegal political activities. ${ }^{23}$

Given the value they placed on education, 1966 university students would probably hold post-1996 MPs in low esteem, think slightly better of ministers, and admire higher civil servants. The students' low opinions of the capacities of MPs and middling regard for ministers would likely leave them unenthusiastic about Parliament as a lawmaking body or as a countervailing check on the executive branch. They would be astounded by the efforts of the Sixth Parliament (1996-2001) to restrain government departments and the president (see Kasfir \& Twebaze 2009). The recovery of initiative by the executive, particularly the president, after that would remind them of Obote's domination of the National Assembly in the 1960s.

On the other hand, 1966 students probably would be surprised to find army officers who had received university education, just as they had, and even more so to discover that the highest ranking officers had originally rebelled in order to create a more promising political regime. That development was a reaction to Uganda's history during the years after 1966. But these students would hardly have been taken aback to learn that many of these officers had become corrupt during their years in power. In addition, the growing militarization of politics in the second phase of the Museveni regime would have struck a familiar chord with these students-although not nearly as forcibly as it would later generations of their compatriots. 24

\section{Conclusion}

The great value in this type of counterfactual analysis is that it directs inquiry into new ways of understanding how specific aspects of earlier political events and regimes influence later ones-or do not. It provides important insights into how much later government structures resemble past ones. In turn, these insights can direct investigation into specific historical factors that may have shaped more recent institutions.

Applying Barkan's careful survey of 1966 university student attitudes to his discerning post-1996 investigations of emerging patterns of governance in the second Museveni period provides a basis for estimating what a particular slice of the highly educated sector of this earlier Ugandan society would have found familiar in the later regime. A surprising number of basic features in current Ugandan governance would likely strike these students as entirely familiar. They would not be surprised to see competitive individual and party politics shrink toward one-person rule. 
Nor would they be shocked to discover the growing militarization of politics. However, they probably would be startled to discover how much patronage and corruption had grown and how important it had become to the financing of political organizations and activities.

As careerists, these students would be likely to sympathize with the large number of contemporary officials who do not join demonstrations for more open and democratic government. In particular, the sizeable proportion of the 1966 students who showed a preference for an authoritarian technocratic government would not support moves to deepen democracy, still a fraught arena in Ugandan politics. These students would understand why most officials would be willing to serve any government that provided them security. Still, given their likely anxieties upon discovering that in 2011, just as in 1966, personal rule appeared to trump the rule of law in Uganda, they probably would wonder, together with Barkan, what it might take to put Ugandan politics on a more secure, more lawful, and less corrupt basis.

\section{References}

Atuhairwe, Alex B. 2005. “A World Bank Commissioned Report Says Uganda May Be Plunged into a Civil War If President Yoweri Museveni Pushes for a Third Term." The Monitor (Kampala), May 18.

Awolich, Abraham A. 2014. "The Question of Ugandan Troops in South Sudan." Weekly Review, March 4. Juba: The Sudd Institute.

Barkan, Joel D. 1975a. An African Dilemma: University Students, Development and Politics in Ghana, Tanzania and Uganda. Nairobi: Oxford University Press.

—. 1975b. "Elite Perceptions and Politics in Ghana, Tanzania and Uganda." In University Students and African Politics, edited by William John Hanna, 187-214. New York: Africana Publishing Company.

— 2005. "Uganda: An African 'Success' Past Its Prime?” In Challenges and Change in Uganda, 9-25. Washington, D.C.: Woodrow Wilson International Center for Scholars.

—. 2011. "Uganda: Assessing Risks to Stability." A Report of the CSIS Africa Program. Washington, D.C.: Center for Strategic \& International Studies.

Barkan, Joel D., et al. 2004. "The Political Economy of Uganda: The Art of Managing a Donor-Financed Neo-Patrimonial State.” Washington, D.C.: World Bank.

Busharizi, Paul. 2005. "A World Bank-Commissioned Study Has Recommended Aid Cuts to Uganda over the Next Three Years." The New Vision (Kampala), May 17.

Kasfir, Nelson, and Stephen Hippo Twebaze. 2009. "The Rise and Ebb of Uganda's No-Party Parliament." In Legislative Power in Emerging African Democracies, edited by Joel D. Barkan, 73-108. Boulder, Colo.: Lynne Rienner.

Lebow, Richard Ned. 2000. "What's So Different about a Counterfactual?" World Politics 52 (4): 550-85.

- 2009. "Counterfactuals, History and Fiction." Historical Social Research 34 (2): $57-73$.

Mujaju, Akiiki B. 1987. "The Gold Allegations Motion and Political Development in Uganda.” African Affairs 86 (345): 479-504. 
Tetlock, Philip E., and Aaron Belkin. 1996. "Counterfactual Thought Experiments in World Politics: Logical, Methodological, and Psychological Perspectives." In Counterfactual Thought Experiments in World Politics: Logical, Methodological, and Psychological Perspectives, edited by Philip Tetlock and Aaron Belkin, 3-38. Princeton, N.J.: Princeton University Press.

Thomas, M. A., and Joel Barkan. 1998a. "Corruption and Political Finance in Africa: Final Report.” World Bank. Washington, D.C.: World Bank.

- 1998b. "Corruption and Political Finance in Uganda: Final Report." World Bank. Washington, D.C.: World Bank.

\section{Notes}

1. I thank Nic Cheeseman for suggesting this question.

2. These stipulations provide a defensible procedure for selecting the antecedent in this kind of counterfactual, although less plausibly in restricting the consequent. Nevertheless, they provide a clear, if somewhat artificial, boundary for deciding what can serve as evidence.

3. I thank Melissa Thomas and an anonymous reviewer for proposing this alternative framing.

4. The other survey asked the students to evaluate their experiences at the college. At $63 \%$, the response rate for each survey was impressively high.

5. This fact weakens both Barkan's analysis of his Ugandan data and my argument. The omission is puzzling, as Barkan asked respondents about their citizenship.

6. Barkan also offered accounts of the strikingly different political contexts in Tanzania (which integrated the students into the government's commitment to socialism) and Ghana (which saw student support for the military government that overthrew President Kwame Nkrumah). Despite these differences, overall he found that university students in all three countries had generally similar values, attitudes, and career expectations.

7. Replicating Barkan's study on current Ugandan students who have few career prospects in government would be fascinating.

8. To demonstrate that these students were ready to act politically when their prospects for high paying jobs were removed, Barkan (1975a) discusses the march of Tanzanian university students to State House in Dar es Salaam in October 1966. They demonstrated in order to object to government plans to bond most of them to five years of teaching at a secondary school after graduation and their subsequent rustication to their home areas. This event occurred a year before he administered his survey there.

9. On the first issue, they scored 2.7 on a five-point Likert scale (0-4), averaging slightly higher (more technocratic) than their Tanzanian and Ghanaian counterparts. On the second issue they scored 2.0 on a five-point Likert scale (0-4), averaging slightly higher (more democratic) than their Tanzanian and Ghanaian counterparts.

10. The ratio among Tanzanian students was 2.4 to 1 and among Ghanaians 1.8 to 1 .

11. Barkan also published much of his discussion of student perceptions of incumbent elites as a chapter in William Hanna's edited volume, University Students and African Politics (Barkan 1975b).

12. Ghanaian and Tanzanian students expressed roughly similar patterns. However, these students also ranked the qualification of army officers as significantly higher. 
13. Barkan defined positive and negative perceptions according to whether or not a respondent thought that ministers were highly qualified and made significant contributions to national development. However, these perceptions may have been influenced more strongly by whether students belonged to the government or an opposition party. Barkan asked respondents about their membership in the 1960s political parties, but oddly, he did not present any analysis of whether party membership affected their political perceptions, particularly regarding whether they believed they could influence government decisions.

14. This project began with three policy studies carried out for the World Bank. It also led to a book chapter and later a report for an NGO (Thomas \& Barkan 1998a,1998b; Barkan et al. 2004; Barkan 2005; Barkan 2011).

15. The "Movement" was the name given to the NRM in the 1996 constitution. It was intended officially to be open to all Ugandans and to serve as the political framework for nonpartisan elections at every level.

16. Because the World Bank's "Articles of Agreement" prohibit interference in the political affairs of any member, Bank officials decided not to make public this research into relationships among corruption, patronage, and financing political organizations and activities. They even banned internal distribution of the 2004 report (personal communication, January 2015). However, both the 1998 and the 2004 reports were almost immediately leaked to local newspapers (for the 2004 report, see Busharizi 2005; Atuhairwe 2005). Ironically, this meant that only World Bank staff were denied use of these reports.

17. They provided estimates for Ugandan campaign spending and the likelihood that it drove MP candidates to use official and military resources illegally as well as pushing them into debt.

18. Barkan presented an overview of these points, including allegations of cases of corruption involving the president's family, in a public conference at the Woodrow Wilson Center. He called on donors to admit these realities and reduce their support. The conference papers were subsequently published (Barkan 2005).

19. At this point the Movement became a political party called the National Resistance Movement Organization (NRMO).

20. Barkan was prophetic in predicting Ugandan military intervention in response to potential "instability in South Sudan" (2011:20). A civil war broke out in South Sudan on December 15, 2013. Some Ugandan troops were already in the country pursuing the LRA; others entered soon after to defend the South Sudan government against its rebels (see Awolich 2014).

21. The exception might be the small subset of Ugandan students whom Barkan identified as preferring "participatory democracy." They may have been members of opposition parties in 1966. Barkan does not present data to examine whether membership in an opposition party correlated with preference for participatory democracy. If it did, such students would probably sympathize with post-1996 opposition parties.

22. In an effort to topple Obote constitutionally, a parliamentary motion to investigate Idi Amin, then Obote's chief ally in the army, for personally profiting from gold smuggling from the Congo (then Zaire) passed, in Obote's absence, with the support of all but one of the MPs in the governing party present at the debate, including several ministers. In his speech in support, the mover also implicated Obote and two of his closest ministers (see Mujaju 1987). A Commission of Inquiry cleared Obote, but its record was not published until many 
years after Barkan conducted his survey. I appreciate Yoga Adhola's reminder that I needed to correct my original account.

23. Several district and kingdom elections as well as the "Lost Counties" referendum held before late 1966 may have provided some students, mainly those from areas holding elections, with information about unusual methods for acquiring funds for political campaigning.

24. By late 1966 Ugandan students had become aware of the army mutiny in 1964 and the involvement of security agents in the 1964 Nakulabye "massacre," the Rwenzururu uprising in western Uganda from 1963, and most spectacularly, the army's attack on the Buganda King's palace in May 1966. In addition, they understood that the desertion of Obote by many of his political allies in early 1966 had led him to rely more heavily on the army. 